\title{
Soil Contaminated with Glyphosate: Can Vermicompost Be Considered a Bioremediation Agent?
}

\author{
Fernanda Benetti \& Lívia B.F. Pigatin \\ Researcher, Chemistry Institute of São Carlos - University of São Paulo \\ Maria O.O. Rezende (Corresponding author) \\ Chemistry Institute of São Carlos, Trabalhador Sãocarlense Ave 400, P.O. Box 780, São \\ Carlos - SP, 13560-970, Brazil. E-mail: mrezende@iqsc.usp.br
}

Received: August 15, 2017 Accepted: September 4, 2017 Published: September 12, 2017

doi:10.5296/jas.v5i3.11696

URL: https://doi.org/10.5296/jas.v5i3.11696

\begin{abstract}
The efficiency of the addition of vermicompost in relation to the decontamination of red latosol was evaluated against acute toxicity, biomass gain and reproduction of Eisenia foetida (earthworms) incubated in the contaminated soil. The soil was spiked to different concentrations of glyphosate from $96 \mathrm{mg} \mathrm{kg}^{-1}$ (recommended by the manufacturer) to 10000 $\mathrm{mg} \mathrm{kg}-1$ to simulate contamination by shedding of the herbicide. To evaluate the effect of vermicompost in the soil contaminated with $10000 \mathrm{mg} \mathrm{kg}^{-1}$ glyphosate, $15 \mathrm{~g}$ of vermicompost, totaling 3\%, was added to the soil. The incorporation of vermicompost to the soil inhibited earthworm mortality. However, even the dose of $96 \mathrm{mg} \mathrm{kg}^{-1}$ presented deleterious effects on the reproduction of $E$. foetida. It can be concluded that the addition of vermicompost to soil contaminated with glyphosate attenuates the deleterious action of the herbicide on E. foetida.
\end{abstract}

Keywords: bioremediation, contaminated soil, glyphosate, Eisenia foetida (earthworms) 


\section{Introduction}

Brazil leads the world in the consumption of pesticides; in the 2010/2011 harvest, 936,000 tons of pesticides were consumed, costing US $\$ 8.5$ billion among the 10 companies that control $75 \%$ of this market in the country. Since 2009, the country is the world's largest consumer of pesticides, using an average of one million tons per year. (Rigotto et al. 2014) The side effects of high pesticide use on the soil ecosystem have been little studied in relation to nontargeted organisms. (Buch et al., 2013) High pesticide use may ultimately compromise soil, water, air, food and human health; therefore, there is a great need for in this area.

The herbicide glyphosate (N-phosphonomethyl glycine) has a relatively low cost and excellent agronomic efficiency, factors reflected in its extensive application. Glyphosate is the active ingredient of the commercial herbicide Roundup ${ }^{\circledR}$, marketed since 1974, and its use is likely to increase as it is one of the most commonly used herbicides in genetically modified crops. Cutaneous exposure to glyphosate has been evaluated as a possible agent contributing to Parkinson's disease due to its chemical similarity with glycine, a necessary cofactor for the activation of N-methyl-D-aspartase, which controls excitatory actions in the central nervous system and is involved in memory and learning. (Anadón et al., 2009)

The primary mode of glyphosate action occurs by interference with the production of aromatic amino acids and other aromatic compounds in plants, which is possible due to the competitive inhibition of 5-enolpyruvylshikimate-3-phosphate synthase, the enzyme responsible for the synthesis of an intermediate in the biosynthesis of phenylalanine, tyrosine and tryptophan.

Thus, plants cannot produce the essential amino acids for their survival, which causes decreased growth, rupture and cellular death. (Piola et al., 2013; Hale et al., 2011)

It is known that the addition of vermicompost in soil can retain pesticides, making them unavailable to the environment, depending on the $\mathrm{pH}$ of the medium, the soil characteristics and the pesticide itself. The incorporation of vermicompost to the soil contributes to the maintenance of the soil organic matter cycle. The action of earthworms and the microorganisms that live in their digestive tracts converts and stabilizes organic wastes into a nutrient-rich, humus-like material called vermicompost.

The earthworms act as microbioreactors that stabilize the new organic matter and transform it into a more refractory material. (Dores-Silva et al. 2015)

In this paper, filter cake and cattle manure were used to produce vermicompost, which was added to soil contaminated with glyphosate. The efficiency of the addition of vermicompost in relation to the decontamination of this soil was evaluated against acute toxicity, biomass gain and reproduction of Eisenia foetida (earthworms) incubated in the contaminated soil. Filter cake is a solid waste obtained from the sugar and ethanol industry on a large scale in the region of São Carlos; consequently, it is readily available. (Pigatin et al, 2016) 


\section{Materials and Methods}

\subsection{Soil Characterization}

The red latosol used for conducting the toxicity experiments was collected on a farm in the region of São Carlos, SP, Brazil, in a forested, uncultivated area (21 $\left.{ }^{\circ} 56^{\prime} 6^{\prime \prime} \mathrm{S}, 47^{\circ} 54^{\prime} 16^{\prime \prime} \mathrm{W}\right)$. Soil samples were air dried, ground and sieved through a $2.5 \mathrm{~mm}$ mesh width and characterized for particle size (ABNT, 1986; ABNT, 1984), pH, organic matter and total carbon. (Jackson, 1958)

\subsection{Vermicompost Preparation}

The mixture of filter cake and cattle manure $(3: 1 \mathrm{w} / \mathrm{w})$ was composted in piles $\left(2.25 \mathrm{~m}^{3}: 2.5\right.$ $\mathrm{m}$ long $\mathrm{x} 2.5 \mathrm{~m}$ wide $\mathrm{x} 1 \mathrm{~m}$ high) until the composting process returned to the mesophilic phase (observed by daily temperature readings). After this period, the mixture was vermicomposted by $500 \mathrm{E}$. foetida. The total time of the process was 135 days. The proportion of residue was calculated to obtain an initial ratio of $\mathrm{C} / \mathrm{N}$ between 20 and 30 per pile. (Pigatin et al. 2016)

\subsection{Toxicity Tests}

The toxicity tests followed the Brazilian Guidelines for the care and use of animals for scientific and teaching purposes (DBCA, of the Ministry of Science, Technology and Innovation, 2013). In Brazil, according to the Agrofit (Phytosanitary Pesticides System Ministry of Agriculture, Livestock and Food Supply), there are 49 registered products with glyphosate as the active ingredient for use in 22 crops. (MAPA, 2016) A commercial formulation containing $48 \mathrm{~g} \mathrm{~L}^{-1}$ of glyphosate was used for this experiment.

Approximately $500 \mathrm{~g}$ of dry red latosol (dry to air, $30 \%$ of humidity) was placed in sturdy plastic containers $(15 \mathrm{~cm} \times 15 \mathrm{~cm} \times 10 \mathrm{~cm}$, each with a rounded bottom and perforated cover) and humidified to approximately $60 \%$ moisture content. The concentrations of glyphosate in the dry red latosol used for the assembly of the tests were $96 \mathrm{mg} \mathrm{kg}^{-1}$ (recommended by the manufacturer) and $3000,4500,6000,7500$ and $10000 \mathrm{mg} \mathrm{kg}^{-1}$ to simulate contamination by shedding of the herbicide. Adequate volumes of the commercial formulation were taken, and they were mixed very well into the soil.

The methodology was performed according to ISO 11268-1, 11268- 2 and ASTM E-1676. (ISO, 1998; ISO, 1993; ASTM, 2012; MCTI, 2013) Experiments followed the design of $1 \times 6 \times 5$, that is, one type of treatment (involving glyphosate formulation) in six different concentrations and five replicates. Five extra samples containing red latosol without glyphosate were used as a reference for a total of 35 vessels.

To evaluate the effect of vermicompost in the soil contaminated with glyphosate in the higher concentration, five more vessels were prepared, each with $10000 \mathrm{mg} \mathrm{kg}^{-1}$ plus $15 \mathrm{~g} \mathrm{(3 \% )} \mathrm{of}$ vermicompost homogenized into the soil. Then, 10 adult earthworms were placed in each of the 40 vessels.

For the acute toxicity and biomass tests, on days $0,7,14,21$ and 28 , earthworms were 
removed from the vessels, washed in running water, dried and weighed. For the acute toxicity, earthworm deaths occurring in the first two weeks, until the 14th day, were evaluated. Mortality was determined by counting the number of dead earthworms. They were considered dead when they neither moved nor responded to tactile stimuli. In the event of a missing earthworm, it was considered dead. For the biomass evaluation, the total biomass gain or loss percentages were calculated and analyzed for each week until the 28th day.

On the 28th day, after removal of the earthworms, the experiment continued until the 56th day. It is worth noting that the optimal conditions for the development of new earthworms were maintained. On the 56th day, cocoons, eggs and/or young earthworms were counted.

\subsection{Statistical Analysis}

The results obtained in the toxicity tests were analyzed using the Dunnett test. ${ }^{[16]}$ This statistical procedure allows for the comparison of any dosage applied in relation to a reference group. If the $\mathrm{P}$ value obtained in the test is $<0.05$, then there are significant differences between the dosages and the reference group. If $\mathrm{P}>0.05$, the doses evaluated are statistically equal to the reference.

All data were obtained using good laboratory practices.

\section{Results and Discussion}

The toxicity tests were carried out as a tool to study the proposed remediation of soils contaminated with glyphosate using vermicompost; for this purpose, two evaluation strategies were adopted. The first strategy was to simulate cases involving a spill, a typical case of an environmental accident where no one is certain of the amount of material that was absorbed, but the concentration is beyond the limits allowed by international laws. Another strategy was the possibility of using a potentially remediated soil for any further agricultural practice. For this, it was stipulated to apply $3 \%$ of vermicompost in the most highly contaminated soil samples to know whether this amount would be enough for their remediation and subsequent agricultural use.

\subsection{Soil Characterization}

ASTM E-1676 recommends toxicity testing to be done in artificial soil (10\% peat, 20\% clay material (kaolinite) and 70\% silica). However, the use of natural soil provides better accuracy of the experiment, as the presence of other minerals (silicate, iron and aluminum oxides and carbonates) can also interfere with the development of the earthworms. Thus, we chose to use natural soil samples to better mimic environmental conditions. (ASTM, 2012)

The red latosol used for conducting the toxicity experiments has a predominantly sandy grain size, with $39.2 \%$ sand, $27.5 \%$ silt and clay fraction of $12.5 \%$. Thus, the soil was classified as a fine to medium dark brown silty sand with organic matter. Table 1 presents the results for acidity $(\mathrm{pH})$, humidity, organic matter and total carbon. 


\section{Al Macrothink}

Table 1. Chemical attributes of the red latosol samples studied

\begin{tabular}{c|c|c|c}
\hline $\mathbf{p H}$ & Humidity (\%) & Organic matter (\%) & Total carbor \\
\hline $4.12 \pm 0.37$ & $24.19 \pm 0.90$ & $5.10 \pm 0.18$ & $3.05 \pm 1.47$ \\
\hline
\end{tabular}

The results show that the evaluated red latosol was acidic: $\mathrm{pH}=4.12 \pm 0.37$. Although earthworms show a higher percentage of survival at a $\mathrm{pH}$ between 5 to 6 , the high acidity of the soil did not significantly influence the experiments because E. foetida have calciferous glands, which allow them to control the acidity of the medium through the release of calcium carbonate secretions. (Primavesi, 2002)

According to the results obtained by Cherubin et al. (2015) and Silva et al. (2015), the organic matter of the soil can complex xenobiotics and make them unavailable to the earthworms. The soil was classified as a fine to medium dark brown silty sand containing approximately $5 \%$ organic matter. Therefore, it was expected that the addition of $3 \%$ vermicompost, which is a nutrient-rich organic, humus-like material, would correspond to an increase of approximately $60 \%$ organic matter. This increment favors the interaction of the herbicide with the added organic matter and, therefore, makes the herbicide unavailable to the environment. By immobilizing it, its residence time increases, which can lead to its degradation.

\subsection{Acute Toxicity Tests}

Figure 1 shows the mean percentage mortality during exposure of E. foetida to a gradation of concentrations of a commercial glyphosate formulation for 14 days.
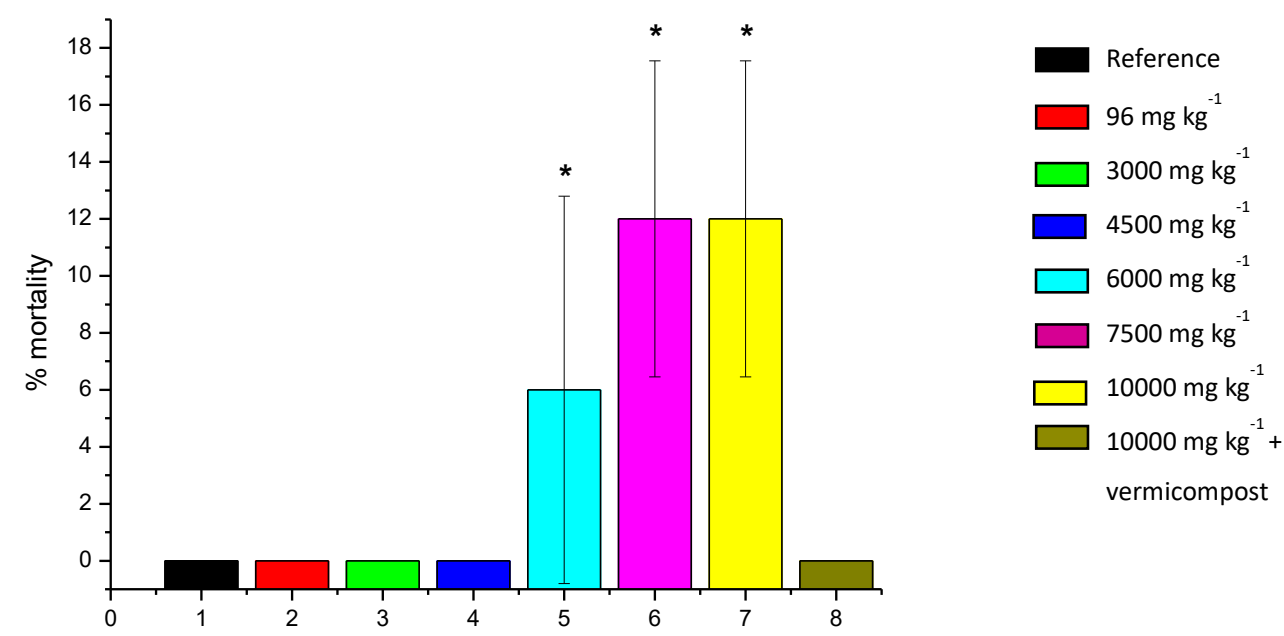

Figure 1. Mean mortality $(\mathrm{n}=5)$ of earthworms $($ E. foetida) after 14 days of exposure to different concentrations of a commercial glyphosate formulation in natural soil. $*=$ 


\section{Macrothink

Statistically significant difference $(\mathrm{P}<0.05)$ compared to the reference according to the Dunnett test. Error bars represent standard deviations.

It is clear in Figure 1 that the highest mortality rate was $12 \pm 6 \%$. The mortality percentages between the reference sample and the glyphosate concentrations of 96, 3000, 4500 and 10000 $\mathrm{mg} \mathrm{kg}^{-1}+3 \%$ vermicompost at the $95 \%$ significance level show no significant differences among each other $(\mathrm{P}>0.05)$, and the events of differences between groups should be discarded. The same does not occur at glyphosate concentrations of 6000, 7500 and 10000 $\mathrm{mg} \mathrm{kg}^{-1}$, where $\mathrm{P}<0.05$, indicating the results of mortality are significantly different from the reference group.

The addition of $3 \%$ vermicompost to the soil contaminated with $10000 \mathrm{mg} \mathrm{kg}^{-1}$ glyphosate cancels out the deleterious effect of glyphosate on earthworm mortality.

\subsection{Biomass Tests}

Biomass tests are important to check for differences in the behavior of E. foetida after the addition of glyphosate in the red latosol. Santadino et al. (2014) found that the biomass and the number of earthworms can be affected by the regular use of herbicides in agriculture. In another study, Piola et al. (2013) affirmed that contaminants can reduce earthworms' available energy for growth, since detoxification processes are energy demanding. Figure 2 shows the results obtained for the biomass studies after 28 days of exposure to different concentrations of a commercial glyphosate formulation in the soil.

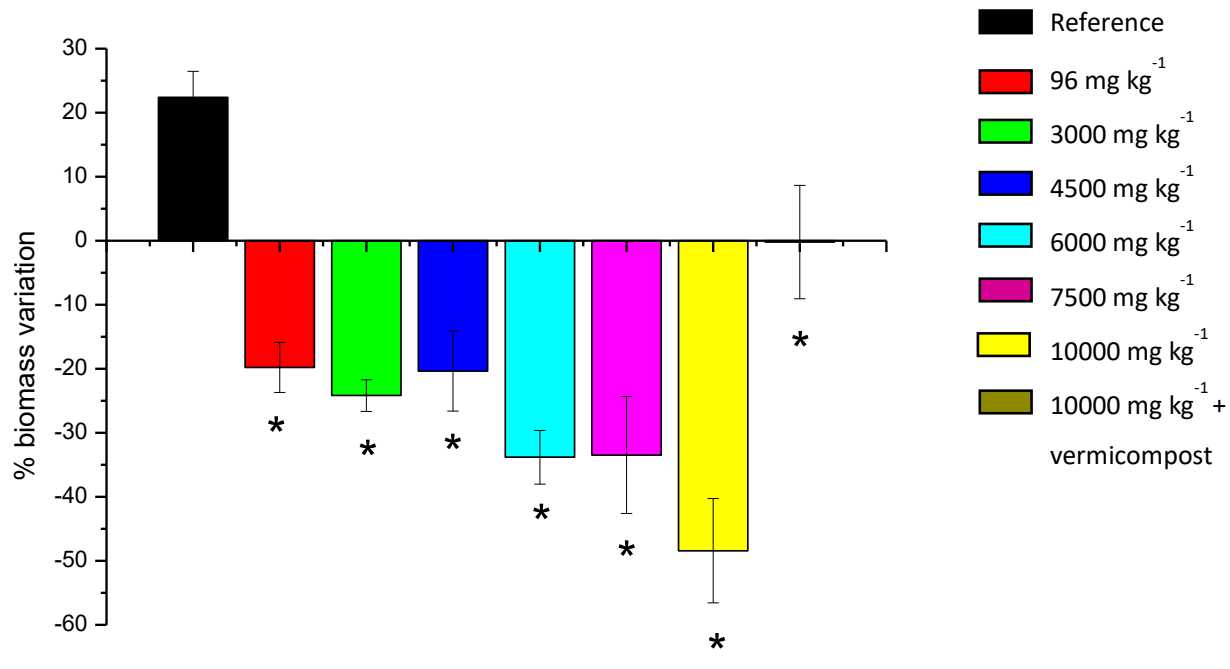

Figure 2. Mean biomass variation $(\mathrm{n}=5)$ of earthworms (E. foetida) after 28 days of exposure to different concentrations of a commercial glyphosate formulation in natural soil. $*=$ Statistically significant difference $(\mathrm{P}<0.05)$ compared to the reference according to the Dunnett test. Error bars represent standard deviations. 
According to Figure 2, all dosages showed different behavior in comparison to the reference experiment. Even in the experiment in which vermicompost was applied, no gain of biomass was observed. In contrast, there was a slight weight loss, which indicates a deleterious effect of glyphosate on E. foetida.

In the same period (28 days), weight loss and the mortality of adult organisms were observed. Weight loss increased with an increasing concentration of glyphosate in the soil, except when adding vermicompost.

The surviving adult organisms showed morphological changes, mainly thinning and fragmentation. Behavioral changes (slow response to mechanical stimuli) were also observed. These observations were related directly to the increase in herbicide concentration. To strengthen the evidence that a concentration of $6000 \mathrm{mg} \mathrm{kg}^{-1}$ compromises the development of earthworms, we calculated the percentage of mortality at 28 days, as shown in Figure 3.

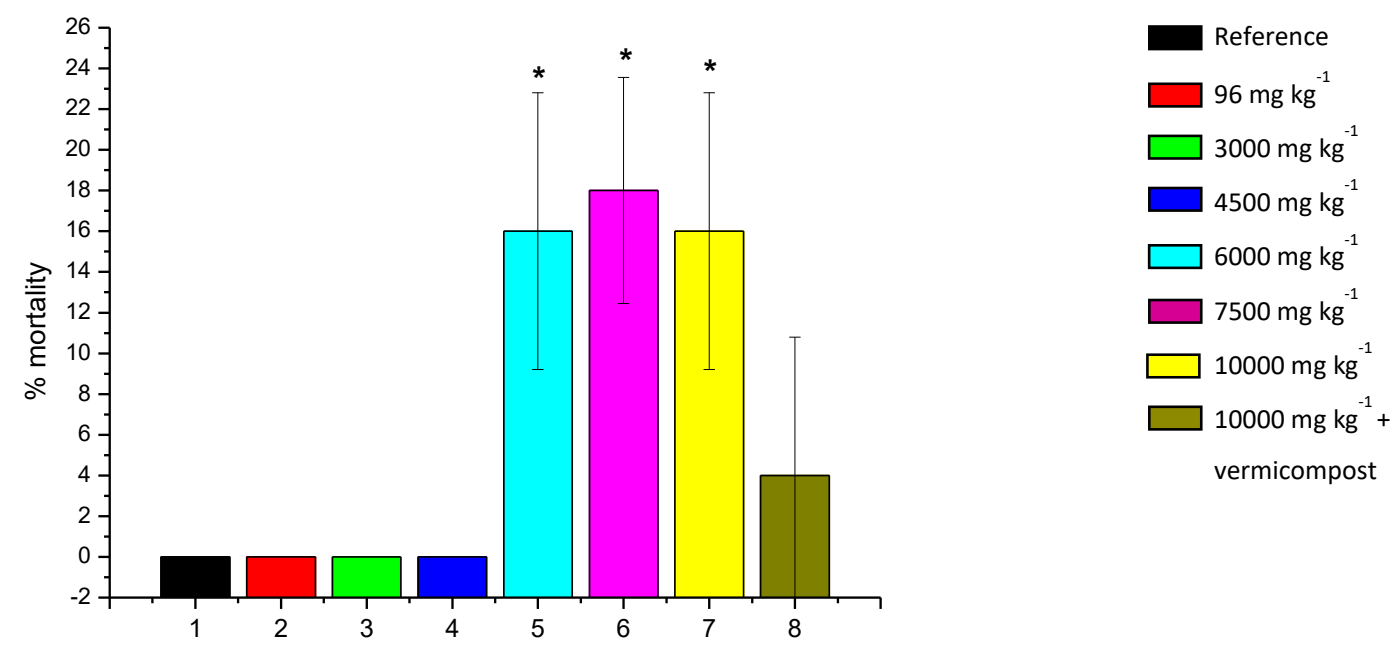

Figure 3. Mean mortality ( $\mathrm{n}=5$ ) of earthworms (E. foetida) after 28 days of exposure to different concentrations of a commercial glyphosate formulation in natural soil. * $=$ Statistically significant difference $(\mathrm{P}<0.05)$ compared to the reference according to the Dunnett test. Error bars represent standard deviations.

By evaluating the tests (Figure 3), it is possible to observe that glyphosate interferes with the development of earthworms even in the presence of vermicompost. Although the percentage of mortality was lower after the incorporation of vermicompost compared with 6000, 7500, or $10000 \mathrm{mg} \mathrm{kg}^{-1}$ of glyphosate in the soil, some individuals also experienced a slight weight loss. It cannot be said, therefore, that the incorporation of vermicompost to soil contaminated with glyphosate $\left(10000 \mathrm{mg} \mathrm{kg}{ }^{-1}\right)$ cancels out the deleterious effect of the herbicide on earthworms. However, it can be concluded that this deleterious effect is mitigated.

García-Pérez et al. (2013) studied earthworms present in coffee crops contaminated by glyphosate, and they reported that the worms can act as indicators of soil disturbance. 


\section{Macrothink Institute ${ }^{T M}$}

However, their results noted that the study should be carried out over a long-term period of years to clarify the likely herbicide relationship to changes in earthworms.

\subsection{Reproduction Tests}

In accordance to the standards established by the ISO $11268-2^{[12]}$, the reproduction test is considered valid if there are at least 30 juvenile worms in each replicate. Santadino et al. argued that the most sensitive parameter for toxicity analysis is the evaluation of the transition body for young adults or the evaluation of the reproduction process. Any change in this dynamic suggests strong sub-lethal effects and can lead to the local extinction of the population. (ISO, 1998; Santadino, 2014)

Figure 4 presents the reproduction data (presence of juvenile earthworms and eggs).

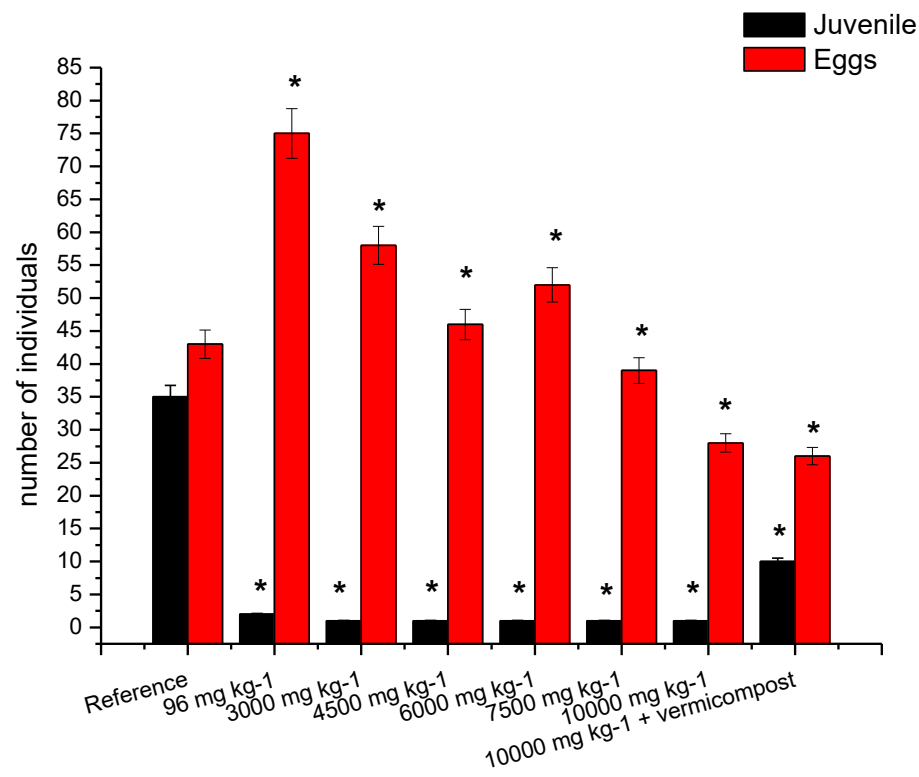

Figure 4. Earthworm reproduction (E. foetida), juveniles and eggs after 56 days of exposure to different concentrations of a commercial glyphosate formulation in natural soil. $*=$ Statistically significant difference $(\mathrm{P}<0.05)$ compared to the reference according to the Dunnett test. Error bars represent standard deviations.

It can be observed in Figure 4 that the addition of glyphosate in the soil interferes with the production of eggs, by hindering their hatching, since the number of juvenile earthworms decreases significantly with the addition of the herbicide. It was also noted that the addition of vermicompost can make the herbicide unavailable to the environment, since the number of juveniles shows a slight increase in the sample where vermicompost is present, even in a great amount. It is interesting to note that in another reproduction test, Correia and Moreira (2010) found no juvenile earthworms in any experiment evaluating glyphosate concentrations up to $1000 \mathrm{mg} \mathrm{kg}^{-1}$ in soil. García-Torres et al. (2014) found a significant decrease in juveniles from $5000 \mathrm{mg} \mathrm{kg}^{-1}$ of glyphosate in soil.

According to the results presented in this work, it is possible to note that, under the conditions of the experiment, it cannot be confirmed that vermicompost is a decontamination agent of 
soils impacted with glyphosate. Although there was no mortality when adding $3 \%$ of vermicompost to a soil contaminated with $10000 \mathrm{mg} \mathrm{kg}^{-1}$ of glyphosate, the biomass of the earthworms and the reproduction of the species were compromised. Further studies are underway to evaluate the addition of vermicompost to other soils spiked with a maximum of $4500 \mathrm{mg} \mathrm{kg}^{-1}$ of glyphosate.

\section{Conclusion}

The study of the toxicity of glyphosate is important to understand the real scope of the impact of its contamination in the soil and living organisms because of its extensive use in crops.

Glyphosate is a herbicide, so its target organisms are plants; but it can also be toxic for soil organisms. The present study showed that glyphosate causes changes in the development of $E$. foetida. Even a dose of $96 \mathrm{mg} \mathrm{kg}^{-1}$ (recommended by manufacturer) presented deleterious effects on the reproduction of E. foetida.

It can be concluded that the addition of vermicompost to a soil contaminated with glyphosate attenuates the deleterious action of the herbicide on E. foetida. Considering that E. foetida can act as an indicator of soil disturbance, it can be inferred that the addition of vermicompost can remediate soil contaminated with glyphosate, even allowing its subsequent agricultural use. However, further studies should include soils under cultivation spiked with other dosages of glyphosate.

\section{Acknowledgements}

The authors thank FAPESP for the scholarship granted to Fernanda Benetti (2011-22651-8) and to Lívia Botacini Favoretto Pigatin (2011-13294-7), for financial aid (2011-13918-0), CNPq (Process number 306715/2013-9) and the Geotechnical Laboratory of the School of Engineering of São Carlos - USP for the determinations of soil particle size.

\section{References}

American Society for Testing and Materials - Astm. (2012). Standard Guide for Conducting Laboratory Soil Toxicity or Bioaccumulation Tests with the Lumbricid Earthworm Eisenia Fetida and the Enchytraeid Potworm Enchytraeus albidus. West Conshohocken: ASTM, 23.

Anadón, A. et al. (2009). Toxicokinetics of glyphosate and its metabolite aminomethyl phosphonic acid in rats. Toxicology Letters, 190(1), 91-95.

https://doi.org/10.1016/j.toxlet.2009.07.008

Associação Brasileira De Normas Técnicas - Abnt. (1986). NBR 6457 - Amostras de solo preparação para ensaios de compactação e ensaios de caracterização. ABNT. Rio de Janeiro, ABNT, 9.

Associação Brasileira De Normas Técnicas - Abnt. (1984). NBR 7181 - Solo - Análise Granulométrica. Rio de Janeiro, ABNT, 13.

Buch, A. C. et al. (2013). Toxicity of three pesticides commonly used in Brazil to Pontoscolex corethrurus (Müller, 1857) and Eisenia andrei (Bouché, 1972). Applied Soil 
Ecology, 69, 32-38. https://doi.org/10.1016/j.apsoil.2012.12.011

Cherubin, M. R. et al. (2015). Sugarcane expansion in Brazilian tropical soils-Effects of land use change on soil chemical attributes. Agriculture, Ecosystems \& Environment, 211, 173-184. http://dx.doi.org/10.1016/j.agee.2015.06.006

Correia, F. V. et al (2010). Effects of glyphosate and 2,4-D on earthworms (Eisenia foetida) in laboratory tests. Bulletin of Environmental Contamination and Toxicology, 85, 264-268. https://doi.org/10.1007/s00128-010-0089-7

Dores-Silva, P. R. et al. (2015). Chemical Differentiation of Domestic Sewage Sludge and Cattle Manure Stabilized by Microbioreators: Study by Pyrolysis Coupled to Gas Chromatography Coupled to Mass Spectroscopy. Journal of Brazilian Chemical Society, 26(5), 860-868. http://dx.doi.org/10.5935/0103-5053.20150046 J.

García-Pérez, J. A. et al. (2013). Earthworm communities and soil properties in shaded coffee plantations with and without application of glyphosate. Applied Soil Ecology, 83, 230-237. https://doi.org/10.1016/j.apsoil.2013.09.006

García-Torres, T. et al. (2014). Exposure Assessment to Glyphosate of Two Species of Annelids. Bulletin of Environmental Contamination and Toxicology, 93, 209-214. https://doi.org/10.1007/s00128-014-1312-8

Hale, S.E. et al. (2011). The effects of chemical, biological, and physical aging as well as soil addition on the sorption of pyrene to activated carbon and biochar. Environmental Science and Technology, 45(24), 10445-53.

International Organization For Standardzation - ISO. (1993). ISO 11268-1 - Soil quality Effects of pollutants on earthworms (Eisenia foetida) - Part 1: Determination of acute toxicity using soil substrate. Geneve: ISO, 18.

International Organization For Standardzation - ISO. (1998). ISO 11268-2 - Soil quality Effects of pollutants on earthworms (Eisenia foetida) - Part 2: Determination of effects on reproduction. Geneve: ISO, 21.

Jackson, M. L. (1958). Soil chemical analysis. Prentice Hall: New York, 498.

Ministério Da Agricultura, Pecuária E Abastecimento - MAPA. (2016). Agrofit - Sistema de Agrotóxicos Fitossanitários. Avaliable:

http://agrofit.agricultura.gov.br/agrofit_cons/principal_agrofit_cons. (Nov, 7, 2016).

Ministério Da Ciência, Tecnologia E Inovação - MCTI. (2013). Conselho Nacional de Controle de Experimentação Animal. Diretriz brasileira para o cuidado e a utilização de animais para fins científicos e didáticos. Brasília: MCTI, 26.

Pigatin, L. B. F. et al. (2016). Chemical study of vermicomposted agroindustrial wastes. International Journal of Recycling of Organic Waste in Agriculture, 5(1), 55-63. https://doi.org/10.1007/s40093-016-0117-7

Piola, L. et al (2013). Comparative toxicity of two glyphosate-based formulations to Eisenia 


\section{Macrothink \\ Journal of Agricultural Studies \\ ISSN 2166-0379 2017, Vol. 5, No. 3}

andrei under laboratory conditions. Chemosphere, 91(4), 545-51.

https://doi.org/10.1016/j.chemosphere.2012.12.036

Primavesi, A. (2002). Manejo Ecológico do Solo. Nobel: São Paulo. 363.

Rigotto, R. M. et al. (2014). Uso de agrotóxicos no Brasil e problemas para a saúde pública. Perspectivas, 30(7), 1-3. https://doi.org/10.1590/0102-311XPE020714

Santadino, M. et al. (2014). Glyphosate Sublethal Effects on the Population Dynamics of the Earthworm Eisenia fetida (Savigny, 1826). Water, Air and Soil Pollution, 225(12), 1-8. https://doi.org/10.1007/s11270-014-2207-3

Silva, B. M. et al. (2015). Critical soil moisture range for a coffee crop in an oxidic latosol as affected by soil management. Soil and Tillage Research, 154, 103-113.

https://doi.org/10.1016/j.still.2015.06.013

Zar, J. H. (2010). Biostatistical Analysis. Prentice Hall: London. 960.

\section{Copyright Disclaimer}

Copyright for this article is retained by the author(s), with first publication rights granted to the journal.

This is an open-access article distributed under the terms and conditions of the Creative Commons Attribution license (http://creativecommons.org/licenses/by/4.0/). 